\title{
NUTRITIVE VALUE OF DIETS WITH INACTIVE DRY YEAST FOR SAANEN GOATS IN THE PERIPARTUM PERIOD ${ }^{1}$
}

\author{
BRUNA SUSAN DE LABIO MOLINA ${ }^{2 *}$, LARISSA RIBAS DE LIMA², LUDMILA COUTO GOMES ${ }^{2}$, \\ LUCIANO SOARES DE LIMA², CLAUDETE REGINA ALCALDE ${ }^{2}$
}

\begin{abstract}
The aim was to evaluate the replacement of soybean meal by inactive dry yeast (Saccharomyces cerevisiae) from sugar cane on nutritive value of diets for Saanen goats in the peripartum. Twenty-four Saanen goats (nine primiparous, $55.35 \pm 4.55 \mathrm{~kg}$ and fifteen multiparous, $73.12 \pm 8.51 \mathrm{~kg}$ ) in prepartum and postpartum periods were distributed in a completely randomized design with a $3 \times 2$ (diet $\times$ parturition order) factorial arrangement. Diets were composed of soybean meal, soybean meal plus dry yeast or dry yeast as protein source, and other ingredients: ground corn, mineral supplement and limestone. The roughage source used was the whole plant corn silage ( $40 \%$ of the total diet). Diets were evaluated as dry matter intake and digestibility of nutrients. The diet with total dry yeast inclusion promoted a reduction on the ether extract intake (postpartum) and ether extract digestibility (prepartum and postpartum), due its lower ether extract content when compared to the other diets. Multiparous goats presented higher intakes for dry matter, nutrients and total digestible nutrients in both evaluated periods due their higher intake capacity. Primiparous goats in postpartum had better coefficients of digestibility for dry matter, organic matter, crude protein and total carbohydrates, and so a higher energetic value, attributed to total digestible nutrients compared to multiparous ones. Dry yeast can replace soybean meal with no changes on nutritive value of diets for Saanen goats.
\end{abstract}

Keywords: Digestion. Intake. Protein source. Saccharomyces cerevisiae.

\section{VALOR NUTRITIVO DE DIETAS COM LEVEDURA SECA INATIVA PARA CABRAS SAANEN NO PERIPARTO}

RESUMO - O objetivo foi avaliar a substituição do farelo de soja por levedura seca inativa (Saccharomyces cerevisiae) de cana-de-açúcar sobre o valor nutritivo de dietas para cabras Saanen no periparto. Vinte e quatro cabras Saanen (nove primíparas, $55,35 \pm 4,55 \mathrm{~kg}$ e quinze multíparas, $73,12 \pm 8,51 \mathrm{~kg}$ ) durante os períodos préparto e pós-parto, foram distribuídas em delineamento inteiramente casualizado, com arranjo fatorial $3 \times 2$ (dieta $\times$ ordem de parto). As dietas foram compostas por farelo de soja, farelo de soja e levedura seca ou levedura seca como fonte de proteína e os demais ingredientes: milho moído, suplemento mineral e calcário. A fonte de volumoso utilizada foi a silagem de milho de planta inteira (40\% da ração total). As dietas foram avaliadas quanto a ingestão de matéria seca e digestibilidade dos nutrientes. A dieta com inclusão total de levedura seca promoveu redução na ingestão de extrato etéreo (pós-parto) e na digestibilidade de extrato etéreo (pós-parto e pré-parto), devido ao seu menor teor de extrato etéreo quando comparada as demais dietas. As cabras multíparas apresentaram maiores ingestões de matéria seca, nutrientes e nutrientes digestíveis totais, em ambos os períodos avaliados, devido a sua maior capacidade de ingestão. As cabras primíparas em pós-parto apresentaram melhores coeficientes de digestibilidade para matéria seca, matéria orgânica, proteína bruta e carboidratos totais, e, portanto, maior valor energético, atribuído aos nutrientes digestíveis totais, comparado as multíparas. A levedura seca pode substituir o farelo de soja sem alterar o valor nutritivo das dietas para cabras Saanen.

Palavras-chave: Digestão. Fonte de proteína. Ingestão. Saccharomyces cerevisiae.

\footnotetext{
*Corresponding author

${ }^{1}$ Received for publication in $04 / 11 / 2014$; accepted in 11/09/2015

Extracted from final work for undergraduate degree in Animal Science from the first and second authors.

${ }^{2}$ Animal Science Department, State University of Maringa, Maringa, PR, Brazil; brunamolina_@hotmail.com, lah_ribas@hotmail.com, ludmilagomes@zootecnista.com.br, luciano.delima@hotmail.com,cralcalde@wnet.com.br.
} 


\section{INTRODUCTION}

Late pregnancy and early lactation correspond to a period during which intense metabolic and physiologic changes occur in females. At the end of pregnancy, the compression of the rumen by fetal growth and the action of some hormones involved in homeorhesis reduces feed intake capacity (RODRIGUES et al., 2006). This reduction can impair meeting nutrient requirements, which can modify physiologic mechanisms of body store mobilization and cause metabolic disturbances after calving (RODRIGUES et al., 2007).

Providing high quality food can avoid nutrient restriction, which promotes low body weight and low productive performance (TERRAZAS et al., 2012).

Inactive dry yeast from sugar cane (Saccharomyces cerevisiae) is used in animal feeding mainly due its protein content, about $42 \%$ (BUTOLO, 2010). It has also a good amino acid profile, and large amounts of B-vitamins and minerals such as zinc and selenium (AMORIM; LOPES, 2009).

Dry yeast was evaluated in studies of productive performance such as goat lactation curves (GOMES et al., 2014a); goat milk production and composition (GOMES et al., 2012); growing and finishing goat kids (LIMA et al., 2011). Also, the replacement of soybean meal by dry yeast as protein source in ruminant nutrition have been showed variable responses on intake and digestibility of dry matter and nutrients (FREITAS et al., 2011; GOMES et al., 2012; LIMA et al., 2012a).

This study was performed to evaluate the replacement of soybean meal by inactive dry yeast (Saccharomyces cerevisiae) from sugar cane on nutritive value of diets for primiparous and multiparous Saanen goats during prepartum and postpartum periods.

\section{MATERIAL AND METHODS}

The experiment was carried out at Fazenda Experimental de Iguatemi, of the Universidade Estadual de Maringá, Paraná, Brazil. Nine primiparous $(55.35 \pm 4.55 \mathrm{~kg})$ and 15 multiparous $(73.12 \pm 8.51 \mathrm{~kg})$ Saanen goats were assigned to a completely randomized design with a $3 \times 2$ (diet $\times$ parturition order) factorial arrangement of treatments. Goats were weighed at the beginning of the study and weekly afterward.

Starting 25 days before the expected kidding date, goats were fed the experimental total mixed diets (TMD) consisting of soybean meal (SB), soybean meal plus dry yeast (SBDY) or dry yeast (DY) as protein source, plus ground corn, mineral supplement, limestone and whole plant corn silage (40\%) following NRC (2007) requirements (Tables 1 and 2).

Table 1. Chemical composition of the ingredients of diets.

\begin{tabular}{lrrrr}
\hline \multirow{2}{*}{ Item $(\mathrm{g} / \mathrm{kg})$} & \multicolumn{3}{c}{ Ingredients } \\
\cline { 2 - 5 } Dry matter $(\mathrm{g})$ & Corn silage & Ground corn & Soybean meal & Dry yeast \\
\hline Organic matter & 313.2 & 880.5 & 877.4 & 951.6 \\
Ash & 958.4 & 988.4 & 930.8 & 962.4 \\
Crude protein & 41.6 & 11.6 & 69.2 & 37.6 \\
Rumen degradable protein $^{1}$ & 75.8 & 104.4 & 532.0 & 410.3 \\
Ether extract $_{\text {Neutral detergent fiber }}$ & 55.0 & 44.1 & 340.9 & 328.2 \\
Total carbohydrates & 25.3 & 36.9 & 29.0 & 1.8 \\
\hline
\end{tabular}

${ }^{1}$ Corn silage, ground corn and soybean meal were estimated from values of degradable protein recommended by the NRC (2007); for dry yeast, degradable protein was estimated from $80 \%$ of crude protein, once $20 \%$ total nitrogen may be nucleic acids (AMORIM; LOPES, 2009).

Goats were housed in individual stalls with free access to water. Fresh feed was provided twice daily at 0930 and $1600 \mathrm{~h}$ and approximately $100 \mathrm{~g} / \mathrm{kg}$ were allowed in orts. The supplied feeds and orts were weighed daily to calculate voluntary intake. After kidding, the goats were milked at 0730 and $1500 \mathrm{~h}$.

Due to differences between the predicted and actual kidding dates, prepartum and postpartum data collection began 10 days before and ended 10 days after kidding, respectively, in order to include a complete sample of goats for all the observational days. Feed intake was recorded daily and samples of TMD and orts were taken at -10 to -5 days (before partum) and +10 to +15 days (after partum) in each collection period, and pooled by goat within each period (prepartum and postpartum). Apparent total tract digestibility was evaluated over 6 days in each collection period. Samples of feces were collected from the exit of the rectum on consecutive days at $0800 ; 1000 ; 1200 ; 1400 ; 1600$ and $1800 \mathrm{~h}$, respectively. All samples were frozen at $-20^{\circ} \mathrm{C}$ for subsequent drying at $55^{\circ} \mathrm{C}$, and ground through a $1 \mathrm{~mm}$ screen in a Wiley mill for further analyses. 
B. S. L. MOLINA et al.

Table 2. Chemical and percentage composition of experimental diets.

\begin{tabular}{lrrr}
\hline & \multicolumn{3}{c}{ Diets } \\
\cline { 2 - 3 } Item $(\mathrm{g} / \mathrm{kg})$ & \multicolumn{1}{c}{ SB } & SBDY & DY \\
\hline Ingredients & & & 400.0 \\
Corn silage & 400.0 & 400.0 & 357.9 \\
Ground corn & 425.3 & 397.3 & - \\
Soybean meal & 166.0 & 97.2 & 234.1 \\
Dry yeast & - & 97.2 & 3.0 \\
Limestone & 3.7 & 3.4 & 5.0 \\
Mineral supplement ${ }^{1}$ & 5.0 & 5.0 & 672.2 \\
\hline Dry matter $(\mathrm{g})$ & 675.0 & 679.3 & 966.3 \\
\hline Organic matter & 956.1 & 958.3 & 33.7 \\
Ash & 43.9 & 41.7 & 156.0 \\
Crude protein & 169.3 & 151.8 & 114.6 \\
Rumen degradable protein & 97.3 & 104.5 & 20.4 \\
Ether extract & 31.1 & 22.6 & 255.7 \\
Neutral detergent fiber & 290.4 & 277.3 & 789.9 \\
Total carbohydrates & 755.7 & 783.9 & $\mathrm{~K}$ \\
\hline
\end{tabular}

${ }^{1}$ Chemical composition (per kg of product) of commercial mixture ${ }^{\circledR}: \mathrm{Ca}-240 \mathrm{~g} ; \mathrm{P}-71 \mathrm{~g} ; \mathrm{F}-710 \mathrm{mg}$ (Max); Mg - 20 g; K 28.2 g; S - 20 g; Fe - 2,500 mg; Cu - 400 mg; Mn - 1,350 mg; Zn - 1,700 mg; Co - 30 mg; I - 40 mg; Se - 15 mg; Cr - 10 mg; vit. A - 135,000 IU; vit. D3 - 68,000 IU; vit. E - 450 IU.

Dry matter was determined according to AOAC method no. 934.01 (1998). Ash was determined by combustion in a muffle furnace according to AOAC method no. 942.05(1998). Total nitrogen (TN) was determined following AOAC method no. 988.05 (1998) and crude protein (CP) was estimated as TN x 6.25. Ether extraction (EE) was conducted according to AOAC method no. 920.39 (1998). Neutral detergent fiber (NDF) was evaluated as described by Mertens (2002) using heat-stable $\alpha$-amylase, without using sodium sulphite. Total carbohydrates (TC) and total digestible nutrients (TDN) were estimated according to the equations described by Sniffen et al. (1992): $\mathrm{TC}(\mathrm{g} / \mathrm{kg} \mathrm{DM})=1000-(\mathrm{CP}+\mathrm{EE}+\mathrm{ash})$ and $\mathrm{TDN}=\mathrm{dCP}+(2.25 \times \mathrm{dEE})+\mathrm{dTC}$, where $\mathrm{dCP}=$ digestible crude protein, $\mathrm{dEE}=$ digestible ether extract and dTC $=$ digestible total carbohydrates.

Indigestible NDF (iNDF) was used as a marker to estimate fecal output and digestibility. Analysis of iNDF was performed by 144 hours of in situ (in rumen fistulated goats) incubation of diets, orts and feces within nylon bags (F57 Ankom) followed by neutral detergent analysis (MERTENS, 2002) by an Ankom ${ }^{200}$ Fiber Analyzer (Ankom Technology Corp., Fairport, NY).

The dietary rumen degradable protein (RDP) content was estimated according to NRC (2007). The values considered were $72.50 ; 42.22$ and $64.07 \%$ for corn silage, ground corn, and soybean meal, respectively. For dry yeast, $80 \%$ of RDP from the crude protein was considered, because about $20 \%$ from the nitrogenous content are nucleic acids (AMORIM; LOPES, 2009).

All results were analyzed using MIXED procedure of Statistical Analysis System Institute (SAS, 1999). Data were analyzed using a completely randomized design with $3 \times 2$ factorial arrangement with the following general model: Yijk $=\mu+\mathrm{Di}+\mathrm{Pj}$ + DPij + eijk, where: Yijk = the dependent variable; $\mu=$ overall mean; Di $=$ fixed effect of diet $i, i=S B$ (soybean meal), SBDY (soybean meal + dry yeast), and DY (dry yeast); $\mathrm{Pj}$ = fixed effect of parturition order $\mathrm{j}, \mathrm{j}=1$ for primiparous and $\mathrm{j}=2$ for multiparous; $\mathrm{DPij}=$ interaction between diet $\mathrm{i}$ and parturition order $\mathrm{j}$; and eijk = random residual error. Results are reported as least squares means and SEM. Significant differences were set at $\mathrm{P} \leq 0.05$.

\section{RESULTS AND DISCUSSION}

There was no significant diet effect on body weight and intakes of dry matter, organic matter, crude protein, rumen degradable protein, neutral detergent fiber, total carbohydrates or total digestible nutrients for goats on either period (prepartum and postpartum) (Table 3). The observed averages for dry matter intake on prepartum period were 1513.7; 1483.2 and $1538.4 \mathrm{~g} /$ day and in the postpartum the averages were $1764.4 ; 1632.5$ and $1660.3 \mathrm{~g}$ /day, for diets soybean meal; soybean meal plus dry yeast and dry yeast, respectively, and this suggests that dry yeast and soybean meal have similar acceptability in peripartum goats. Similarly, other studies have shown no effects of dry yeast on dry matter intake in sheep (AGUIAR et al., 2007) and goats (FREITAS et al., 2011; LIMA et al., 2011).

The replacement of soybean meal by dry yeast in the diets reduced $(\mathrm{P}<0.05)$ ether extract intake for goats in postpartum period (Table 3). This agrees with the results of LIMA et al. (2012a), who reported that feeding dry yeast as a protein source to lactating goats reduced the ether extract intake compared with soybean meal. The explanation for 
this effect may be based on the lower ether extract proportion in dry yeast $(0.18 \%)$ compared to soybean meal $(2.9 \%)$, likely accounted for the observed reduced ether extract intake.

Table 3. Body weight and intake of dry matter and nutrients in Saanen goats.

\begin{tabular}{|c|c|c|c|c|c|c|c|c|c|c|}
\hline & \multicolumn{6}{|c|}{ Treatments $^{1}$} & \multirow[b]{3}{*}{ SEM } & \multicolumn{3}{|c|}{ Main effects (P values) ${ }^{2}$} \\
\hline & \multicolumn{2}{|c|}{ SB } & \multicolumn{2}{|c|}{ SBDY } & \multicolumn{2}{|c|}{ DY } & & & & \\
\hline & $\mathrm{P}$ & $\mathrm{M}$ & $\mathrm{P}$ & $\mathrm{M}$ & $\mathrm{P}$ & $\mathrm{M}$ & & $\mathrm{D}$ & $\mathrm{PO}$ & $\mathrm{D} \times \mathrm{PO}$ \\
\hline \multicolumn{11}{|c|}{ Prepartum } \\
\hline $\mathrm{BW}^{3}$ & 54.8 & 73.6 & 55.5 & 73.9 & 55.7 & 71.8 & 2.35 & 0.97 & $<0.0001$ & 0.95 \\
\hline & \multicolumn{10}{|c|}{ Intake (g/day) } \\
\hline DM & 1291.0 & 1736.4 & 1145.3 & 1821.0 & 1285.7 & 1791.0 & 0.07 & 0.90 & $<0.0001$ & 0.63 \\
\hline $\mathrm{OM}$ & 1238.0 & 1664.6 & 1106.3 & 1756.6 & 1241.0 & 1729.2 & 0.07 & 0.90 & $<0.0001$ & 0.63 \\
\hline $\mathrm{CP}$ & 226.3 & 297.8 & 204.0 & 311.2 & 224.0 & 312.0 & 0.01 & 0.88 & $<0.0001$ & 0.69 \\
\hline RDP & 125.7 & 169.2 & 119.7 & 190.4 & 147.7 & 205.2 & 0.00 & 0.10 & $<0.0001$ & 0.59 \\
\hline $\mathrm{EE}$ & 36.0 & 47.2 & 30.0 & 44.8 & 31.0 & 42.8 & 0.00 & 0.25 & $<0.0001$ & 0.82 \\
\hline NDF & 350.7 & 510.2 & 278.0 & 539.4 & 310.3 & 448.6 & 0.02 & 0.52 & $<0.0001$ & 0.34 \\
\hline $\mathrm{TC}$ & 975.7 & 1319.6 & 888.3 & 1422.4 & 985.7 & 1374.2 & 0.05 & 0.94 & $<0.0001$ & 0.59 \\
\hline TDN & 941.7 & 1267.4 & 905.7 & 1376.2 & 918.0 & 1307.2 & 0.05 & 0.93 & $<0.0001$ & 0.76 \\
\hline \multicolumn{11}{|c|}{ Postpartum } \\
\hline $\mathrm{BW}^{3}$ & 45.5 & 59.0 & 45.1 & 60.5 & 47.2 & 54.8 & 1.94 & 0.90 & 0.00 & 0.62 \\
\hline \multicolumn{11}{|c|}{ Intake (g/day) } \\
\hline DM & 1408.3 & 2120.4 & 1261.6 & 2001.4 & 1250.0 & 2070.6 & 0.09 & 0.70 & $<0.0001$ & 0.94 \\
\hline $\mathrm{OM}$ & 1346.7 & 2027.6 & 1208.7 & 1917.6 & 1208.3 & 2000.2 & 0.09 & 0.73 & $<0.0001$ & 0.93 \\
\hline $\mathrm{CP}$ & 246.0 & 363.4 & 192.3 & 300.8 & 195.0 & 321.8 & 0.02 & 0.07 & $<0.0001$ & 0.93 \\
\hline RDP & 137.0 & 206.2 & 131.7 & 209.0 & 143.3 & 237.0 & 0.01 & 0.46 & $<0.0001$ & 0.78 \\
\hline EE & 46.0 & 66.6 & 28.3 & 45.2 & 25.3 & 42.6 & 0.00 & $<0.0001$ & $<0.0001$ & 0.86 \\
\hline NDF & 355.0 & 582.8 & 285.0 & 533.6 & 278.7 & 502.2 & 0.03 & 0.44 & 0.00 & 0.98 \\
\hline $\mathrm{TC}$ & 1054.3 & 1597.4 & 998.8 & 1571.2 & 988.0 & 1636.6 & 0.07 & 0.95 & $<0.0001$ & 0.91 \\
\hline TDN & 1124.3 & 1555.8 & 1021.7 & 1504.0 & 974.7 & 1570.2 & 0.06 & 0.77 & $<0.0001$ & 0.77 \\
\hline
\end{tabular}

${ }^{1}$ Soybean (SB); Soybean + Dry yeast (SBDY); Dry yeast (DY); Primiparous (P); Multiparous (M); ${ }^{2}$ Diet (D); Parturition order $(\mathrm{PO}) ;{ }^{3} \mathrm{~kg}$.

$\mathrm{BW}=$ body weight; $\mathrm{DM}=$ dry matter; $\mathrm{OM}=$ organic matter; $\mathrm{CP}=$ crude protein; $\mathrm{RDP}=$ rumen degradable protein; $\mathrm{EE}=$ ether extract; $\mathrm{NDF}=$ neutral detergent fiber; $\mathrm{TC}=$ total carbohydrates; $\mathrm{TDN}=$ total digestible nutrients.

Parturition order influenced $(\mathrm{P}<0.05)$ both prepartum and postpartum body weight, intake of dry matter, nutrients and total digestible nutrients, with multiparous goats showing the highest values (Table 3). Similar results have been reported previously by a study in which two-years-old goats presented a higher intake of dry matter and nutrients compared to one-year-old goats fed diets containing dry yeast (ALCALDE et al., 2010). This suggests that intake is strongly affected by age and parity, since they are related to body development and the full capacity of the rumen. Indeed, some factors, such as fiber content and the energetic density of the diet, nutritional requirements and the ruminal capacity of the animals have been reported to regulate dry matter intake capacity in ruminants (PEREIRA et al., 2003). Thus, the higher dry matter intake observed in multiparous occurred mainly due to their higher relative intake capacity.

In the prepartum period, primiparous consumed about 5\% less feed while multiparous consumed about $14 \%$ less feed, than in the postpartum. In fact, in the last three weeks before calving a compression of the rumen by the fetus occurs and dry matter intake can be reduced by about 5 to $10 \%$ (RIBEIRO, 1997). Also, in early lactation, intake capacity is still critical, until the $7^{\text {th }}$ to $11^{\text {th }}$ week, when dry matter intake is completely restored (GOMES et al., 2014b).

The digestibility of dry matter, organic matter, crude protein, neutral detergent fiber and total carbohydrates were similar among diets during prepartum and postpartum (Table 4).

Similarly to these results, when castrated Saanen goats were fed portions of dry yeast $(0,25$, 50,75 and $100 \%$ ) instead of soybean meal, differences in dry matter and nutrient digestibility were not observed (LIMA et al., 2012b). However, the digestibility of dry matter and nutrients can be improved when dry yeast is included in diets for heifers and goat kids, as reported by Martins et al. (2000) and Lima et al. (2011), respectively. 
B. S. L. MOLINA et al.

Table 4. Digestibility of dry matter and nutrients and energetic value of diets in Saanen goats.

\begin{tabular}{|c|c|c|c|c|c|c|c|c|c|c|}
\hline & \multicolumn{6}{|c|}{ Treatments $^{1}$} & \multirow[b]{3}{*}{ SEM } & \multicolumn{3}{|c|}{ Main effects (P values) ${ }^{2}$} \\
\hline & \multicolumn{2}{|c|}{ SB } & \multicolumn{2}{|c|}{ SBDY } & \multicolumn{2}{|c|}{ DY } & & & & \\
\hline & $\mathrm{P}$ & $\mathrm{M}$ & $\mathrm{P}$ & $\mathrm{M}$ & $\mathrm{P}$ & $\mathrm{M}$ & & $\mathrm{D}$ & PO & $\mathrm{D} \times \mathrm{PO}$ \\
\hline \multicolumn{11}{|c|}{ Prepartum } \\
\hline \multicolumn{11}{|c|}{ Digestibility $(\mathrm{g} / \mathrm{kg})$} \\
\hline DM & 704.4 & 709.4 & 753.0 & 719.7 & 690.1 & 717.7 & 0.83 & 0.27 & 0.99 & 0.37 \\
\hline $\mathrm{OM}$ & 729.7 & 731.1 & 774.0 & 736.1 & 718.0 & 736.5 & 0.78 & 0.34 & 0.72 & 0.38 \\
\hline $\mathrm{CP}$ & 683.0 & 701.8 & 729.6 & 733.3 & 657.6 & 714.5 & 0.87 & 0.08 & 0.13 & 0.42 \\
\hline $\mathrm{EE}$ & 888.9 & 878.3 & 907.3 & 886.9 & 819.2 & 791.1 & 1.01 & $<0.0001$ & 0.10 & 0.83 \\
\hline NDF & 389.8 & 445.9 & 417.6 & 440.9 & 338.8 & 410.4 & 1.37 & 0.25 & 0.08 & 0.77 \\
\hline $\mathrm{TC}$ & 735.4 & 732.8 & 784.2 & 736.1 & 729.8 & 739.2 & 0.81 & 0.38 & 0.43 & 0.37 \\
\hline TDN & 729.8 & 730.3 & 790.8 & 749.6 & 716.5 & 735.2 & 0.82 & 0.07 & 0.66 & 0.33 \\
\hline \multicolumn{11}{|c|}{ Postpartum } \\
\hline \multicolumn{11}{|c|}{ Digestibility (g/kg) } \\
\hline $\mathrm{DM}$ & 782.5 & 718.8 & 801.3 & 746.0 & 767.9 & 750.7 & 0.66 & 0.13 & $<0.0001$ & 0.10 \\
\hline $\mathrm{OM}$ & 797.4 & 734.2 & 813.8 & 760.5 & 787.3 & 766.0 & 0.66 & 0.20 & $<0.0001$ & 0.18 \\
\hline $\mathrm{CP}$ & 767.4 & 710.8 & 761.3 & 724.1 & 739.1 & 734.7 & 0.57 & 0.88 & 0.00 & 0.10 \\
\hline $\mathrm{EE}$ & 894.1 & 857.9 & 849.9 & 832.0 & 789.3 & 785.0 & 1.00 & 0.00 & 0.22 & 0.70 \\
\hline NDF & 458.1 & 447.8 & 536.1 & 458.9 & 434.9 & 439.9 & 1.13 & 0.09 & 0.22 & 0.29 \\
\hline $\mathrm{TC}$ & 800.3 & 734.6 & 825.0 & 765.5 & 796.8 & 771.7 & 0.75 & 0.14 & 0.00 & 0.28 \\
\hline TDN & 799.1 & 735.9 & 813.0 & 752.1 & 781.0 & 760.4 & 0.68 & 0.42 & $<0.0001$ & 0.15 \\
\hline
\end{tabular}

${ }^{1}$ Soybean (SB); Soybean + Dry yeast (SBDY); Dry yeast (DY); Primiparous (P); Multiparous (M); ${ }^{2}$ Diet (D); Parturition order (PO).

$\mathrm{DM}=$ dry matter; $\mathrm{OM}=$ organic matter; $\mathrm{CP}=$ crude protein; $\mathrm{EE}=$ ether extract; $\mathrm{NDF}=$ neutral detergent fiber; $\mathrm{TC}=$ total carbohydrates; TDN $=$ total digestible nutrients.

Digestibility is directly influenced by the feed intake, diet composition, degradability, protein to energy ratio and factors related to the animals (VAN SOEST, 1994). So, the reduction $(\mathrm{P}<0.05)$ observed in digestibility of the ether extract, is mainly related to the diet composition, diets with dry yeast presented lower ether extract content. Also, Freitas et al. (2011) reported a linear reduction in ether extract digestibility for goat kids with $0,25,50,75$ and $100 \%$ of dry yeast included in the diets, due to the minimal ether extract content in dry yeast $(0.32 \%)$. Lima et al. (2012b) observed a reduction of ether extract digestibility from the inclusion of $38.5 \%$ of dry yeast in diets for Saanen goats.

Although ether extract digestibility was reduced $(\mathrm{P}<0.05)$ by the inclusion of dry yeast in the diets, the results for total digestible nutrients, in prepartum and postpartum, were not affected. Also, no difference was observed in total digestible nutrients, when soybean meal was replaced by dry yeast (LIMA et al., 2012b). These results may be related mainly to the similar digestibility of crude protein and total carbohydrates observed among the diets (Table 4). The inclusion of dry yeast in diets provided good energetic value for goats; expressed by the following overall averages obtained for total digestible nutrients 742.1 and $773.6 \mathrm{~g} / \mathrm{kg}$, in prepartum and postpartum periods, respectively.

Parturition order did not influence the digestibility of dry matter and nutrients in the prepartum period, however, in postpartum, primiparous goats presented better digestibility for dry matter organic matter, crude protein and total carbohydrates. So, in postpartum, a higher energetic value of the diets, was observed for primiparous than for multiparous goats, with the averages of 797.7 and $749.5 \mathrm{~g} / \mathrm{kg}$, respectively, which contributed to about $6 \%$ more efficiency for total digestible nutrients.

\section{CONCLUSION}

Inactive dry yeast (Saccharomyces cerevisiae) can replace soybean meal in diets for Saanen goats with no changes on nutritive value of diets.

The primiparous goats are more efficient in the use of nutrients of diets than multiparous, in the postpartum period.

\section{ACKNOWLEDGEMENTS}

This project was supported by the Conselho Nacional de Desenvolvimento Científico e Tecnológico - CNPq (Edital MCT/CNPq $\mathrm{N}^{\mathrm{o}}$ 14/2010).

\section{REFERENCES}

AGUIAR, S. R. et al. Performance of feedlot sheep fed with increasing levels of yeast and urea. Acta Scientiarum. Animal Science, Maringá, v. 29, n. 4, p. 411-416, 2007.

ALCALDE, C. R. et al. Performance of dairy goats fed diet with dry yeast as protein source. In: $10 \mathrm{TH}$ INTERNATIONAL CONFERENCE ON GOATS, 
63., 2010, Proceedings... Recife: International Goats Association - IGA, 2010. 1 CD-ROM.

AMORIM, H. V.; LOPES, M. L. Tecnologia sobre processamento de leveduras vivas, inativas e seus derivados: conceitos básicos. In: I CONGRESSO INTERNACIONAL SOBRE USO DA LEVEDURA NA ALIMENTAÇÃO ANIMAL, 2009, Anais... Campinas: Colégio Brasileiro de Nutrição Animal CBNA, 2009. p. 5-19.

Association of Official Analytical Chemists AOAC. Official methods of analysis. 16. ed. Gaithersburg: AOAC, 1998. 1141 p.

BUTOLO, J. E. Qualidade de ingredientes na alimentação animal. 2. ed. Campinas, SP: CBNA, $2010.430 \mathrm{p}$.

FREITAS, H. S. et al. Total digestibility and nitrogen balance in kid goats receiving diets containing dry yeast. Acta Scientiarum. Animal Science, Maringá, v. 33, n. 3, p. 281-286, 2011.

GOMES, L. C. et al. Performance of lactating goats fed diets containing inactive dry yeast. Brazilian Journal of Animal Science, Viçosa, v. 41, n. 10, p. 2249-2254, 2012.

GOMES, L. C. et al. Nutritive value of diets containing inactive dry yeast for lactating Saanen goats. Brazilian Journal of Animal Science, Viçosa, v. 43, n. 1, p. 36-43, 2014a.

GOMES, L. C. et al. The impact of dietary dry yeast on lactation curves of primiparous and multiparous Saanen goats. Acta Scientiarum. Animal Science, Maringá, v. 36, n. 4, p. 405-411, 2014 b.

LIMA, L. S. et al. Sugar cane dry yeast in feeding for growing and finishing goat kids. Brazilian Journal of Animal Science, Viçosa, v. 40, n. 1, p. 168-173, 2011.

LIMA, L. S. et al. Performance of dairy goats fed diets with dry yeast from sugar cane as protein source. Brazilian Journal of Animal Science, Viçosa, v. 41, n. 1, p. 232-236, 2012 a.

LIMA, L. S. et al. Effect of inactive dry yeast from sugar cane as protein source on rumen fermentation in Saanen goats. Brazilian Journal of Veterinary and Animal Sciences, Belo Horizonte, v. 64, n. 1, p. 145-154, 2012b.

MARTINS, A. S. et al. Apparent Digestibility of diets containing corn or cassava hull as energy source and cottonseed meal or yeast as protein source, in heifers. Brazilian Journal of Animal Science, Viçosa, v. 29, n. 1, p. 269-277, 2000.
MERTENS, D. R. Gravimetric determination of amylase-treated neutral detergent fiber in feeds with refluxing in beakers or crucibles: collaborative study. Journal of AOAC International, Gaithersburg, v. 85 , n. 6, p. 1217-1240, 2002.

National Research Council - NRC. Nutrient Requirements of Small Ruminants: Sheep, Goats, Cervids, and New World Camelids. 1. ed. Washington, D.C.: National Academy Press, 2007. $384 \mathrm{p}$.

PEREIRA, E. S. et al. Voluntary intake in ruminants. Semina: Ciências Agrárias, Londrina, v. 24, n. 1, p. 191-196, 2003.

RIBEIRO, S. D. A. Caprinocultura: Criação Racional de Caprinos. 1. ed. São Paulo, SP: Nobel, 1997. $318 \mathrm{p}$.

RODRIGUES, C. A. F. et al. Body condition score and peripartum energy density on performance of dairy goats. Brazilian Journal of Animal Science, Viçosa, v. 35, n. 4, p. 1560-1567, 2006.

RODRIGUES, C. A. F. et al. Effects of body condition score and dietary energy levels on performance of pregnant dairy goats. Brazilian Journal of Animal Science, Viçosa, v. 36, n. 4, p. 945-952, 2007.

SNIFFEN, C. J. et al. A net carbohydrate and protein system for evaluating cattle diets: II. Carbohydrate and protein availability. Journal of Animal Science, Champaign, v. 70, n. 11, p. 3562-3577, 1992.

SAS INSTITUTE. Statistical Analysis System user's guide. Version 6.03. Cary, NC, 1999.

TERRAZAS, A. et al. Undernutrition during pregnancy in goats and sheep, their repercussion on mother-young relationship and behavioural development of the young. Tropical and Subtropical Agroecosystems, Mérida, v. 15, p. 161174, 2012

VAN SOEST, P. J. Nutritional Ecology of the Ruminant. 2. ed. Ithaca, NY: Cornell University Press, 1994. $476 \mathrm{p}$ 